\title{
The Impact of Professional Competence \& Staffing of Internal Audit Function on Transparency and Accountability Case of Zimbabwe Local Authorities
}

\author{
Moses Jachi ${ }^{1} \quad$ Lucky Yona $^{2 *}$ \\ 1. Midlands State University P. Bag 9055 Gweru, Zimbabwe \\ 2. Eastern and Southern African Management Institute P.O. Box 3030, Arusha, Tanzania
}

\begin{abstract}
The study aimed at investigating the impact of internal audit function competence \& staffing on transparency \& accountability in Zimbabwe local authorities. The study adopted professional competence \& staffing as the independent variable and transparency \& accountability as the dependent variable. Survey data was obtained from management and internal audit personnel from local authorities in Zimbabwe using semi-structured questionnaires and focus group discussions. Questionnaire responses were obtained from 182 respondents. Two focus group discussions were held separately with 13 senior managers and 8 Chief Audit Executives from local authorities in Zimbabwe. Regression and multivariate analysis were used to test the hypothesis that internal audit function professional competence $\&$ staffing is positively associated with transparency \& accountability in Zimbabwe local authorities. The study established that there is a significant positive relationship between internal audit function competency dimensions of qualification, experience and training and transparency \& accountability in Zimbabwe local authorities. The study reveals the need to improve and uphold internal audit function competency through creation of an enabling environment to support internal audit functions and guarantee their effectiveness in upholding corporate governance practices. The study recommends the establishment of a centralized Local Government Internal Audit Agency under the Ministry of Local Government, Public Works and National Housing, responsible for coordinating, supervising, monitoring and reviewing local authorities internal audit functions as a stride towards improving public finance management systems and corporate governance practices within the country's public sector.
\end{abstract}

Keywords: Professional Competence \& Staffing, Internal Audit Function, Transparency \& Accountability DOI: $10.7176 /$ RJFA/10-8-15

Publication date: April $30^{\text {th }} 2019$

\section{Introduction}

Contemporary internal audit literature accentuates the need for an improvement in the quality of internal audit function so as to guarantee its effectiveness (Mihret \& Yismaw, 2007), to match its value proposition (Lenz \& Sarens, 2012; Endaya \& Hanefah, 2013; Lenz \& Hahn, 2015). This can be achieved through promoting internal audit competency since it is one of the function's main quality dimensions (Jiang, et al., 2014; Al-Matari, et al., 2014; Abbott, et al., 2016). Professional competence refers to the possession of skills and knowledge required to perform a specifically defined task (Abbott, et al., 2016), which is attained through training and experience (Arena \& Azzone, 2009; Cohen \& Sayag, 2010; Mihret, et al., 2010; Millichamp \& Taylor, 2012; Badara \& Saidin, 2013; Endaya \& Hanefah, 2013; Lenz \& Hahn, 2015).

The internal audit profession has recently been seen to play a very important role in upholding corporate governance best practice requirements (IIA, 2016), thus the profession had shifted towards a proactive and value addition approach, a development that has generally changed stakeholders' view of the profession (Arena \& Azzone, 2009; Mihret, et al., 2010; Soh \& Martinov-Bennie, 2011; Lenz \& Hahn, 2015). This new approach has fostered the profession to look beyond compliance to improvement of the overall organizational performance and governance (Chambers, 2014; IIA, 2016). This value approach however came with commensurate new responsibilities, calling for the need for internal auditors to acquire new skills and competencies (Stewart \& Subramaniam, 2010; Soh \& Martinov-Bennie, 2011). In a bid to foster understanding of the attributes required for internal auditors to meet their enhanced role, the Institute of Internal Auditors through their research foundation has funded a global study, The Competency Framework for Internal Auditing, which established the need for internal audit personnel to have improved skills so as to meet their enhanced job requirements (Burbaby \& Hass, 2009), particularly those within the Public sector (Asare, 2009; Abuazza, et al., 2015). The Performance Standard 2100 of the International Standards for the Professional Practice of Internal Auditing (2012) mandates internal auditors to have the capacity to evaluate and contribute to the improvement of organization wide governance, risk management and control processes (IIA, 2016).

Exploring into ways through which internal audit function quality can be enhanced, some scholars argue against reliance on the competency of internal audit personnel as a stand-alone guarantee for improved organizational performance (Dukic \& Dordevic, 2014). They argue that internal audit task can be deemed complete 
when satisfaction is obtained that organizational defects have been rectified, leaving enough assurance that such a status will be maintained if not improved (Sawyer, 1995), a condition that can only be achieved through adequate management support of the function's existence and subsequent implementation of its recommendations (Sarens \& De Beelde, 2006; Mihret \& Yismaw, 2007; Christopher, et al., 2009; Halimah, et al., 2009; Cohen \& Sayag, 2010). However, for an internal audit function to be perceived effective, it should have the capacity to perform quality engagements (Al-Twaijry, et al., 2003; Cohen \& Sayag, 2010), which is a product of internal audit function competency. This notion was supported by a handful of scholars who pointed that poor staffing and competency is a significant attributes hindering establishments of effective internal audit functions, hence the need to create an enabling environment in support of the endeavor to establish high quality internal audit functions which have the capacity to positively impact corporate governance practices (Cohen \& Sayag, 2010; Mebratu, 2015).

Literature considers that the competency of an internal audit function is determined by qualifications (Mihret, et al., 2010; Cohen \& Sayag, 2010; Alzeban \& Gwilliam, 2014), experience (Arena \& Azzone, 2009; Badara \& Saidin, 2013; Endaya \& Hanefah, 2013; Lenz \& Hahn, 2015) and the size of the internal audit function (Carcello, et al., 2005; Goodwin-Stewart \& Kent, 2006; Gronewood \& Heerlein, 2009; Barua, et al., 2010; Sarens \& Abdolmohammadi, 2011; Anderson, et al., 2012; Alhajri, 2017), with other scholars emphasising that skills and qualifications of the Chief Audit Executive are key dimensions in determining the overall competent nature of an internal audit function (Prawitt, 2003; Pforsich, et al., 2006; Chambers, 2008; Pforsich, et al., 2008; Mihret, et al., 2010). This is because the Chief Audit Executive plays the central role in setting the tone of the function (Soh \& Martinov-Bennie, 2011) through aligning internal audit function activities with the organisation's strategic goals, prioritisation of engagements (Rittenberg \& Anderson, 2006) and optimisation of resources and skills (Hoos, et al., 2015).

Skills development as an integral part of economic empowerment is a responsibility shared by the government, employers and the individual worker (ILO, 2011). The current dynamic business operational environment calls for audit personnel to continue upgrading their skill and knowledge base through continuous professional development (Cohen \& Sayag, 2010; Alzeban \& Gwilliam, 2014), over and above their basic educational qualifications, so that they can be able to understand developments within the system and the constantly changing knowledge of business (Mihret, et al., 2010; Endaya \& Hanefah, 2013). Qualification of internal audit personnel enhances the quality of the internal audit performance in general. This is in line with the agency and resource dependence theories (Hutchinson \& Zain, 2009; Al-Matari, et al., 2014). Relatively, few studies have been carried out to date examining the relationship between qualifications of internal audit personnel and organisational performance particularly in the public sector, justifying the need to further literature on the same (Al-Matari, et al., 2012). This study will also explore the role played by professional certification; training and membership with Institute of Internal Auditors in the context of the chief audit executive on promoting good corporate governance practices.

Prior studies have indicated that the Chief Audit Executive is a key player to the determination of the overall quality of an internal audit function and as such, it is logical to use his competence to represent the competency of an internal audit function (Jiang, et al., 2014; Al-Matari, et al., 2014). Abbott et al (2016) conducted a study examining an interactive model of internal audit function quality, considering competence as one of the function's quality dimensions. The study established that joint presence of independence and competence enhances financial reporting monitoring, thereby promoting transparency and accountability (Abbott, et al., 2016). From a review of previous studies which applied competence as an internal audit function quality dimension (Hutchinson \& Zain, 2009; Prawitt, et al., 2009; Al-Matari, et al., 2014; Abbott, et al., 2016), the current study is expected to establish the existence of a positive relationship between a competent internal audit function and good corporate governance practices which in turn contributes significantly towards the fulfilment of societal expectations.

\section{Statement of the problem}

The need to and means through which organisations can foster and enhance internal audit function quality has gained attention from previous studies (Jiang, et al., 2014; Al-Matari, et al., 2014; Abbott, et al., 2016), majority of whom consent to the need for internal auditors to improve on their competencies and skills so as to meet their enhanced job requirements (Cohen \& Sayag, 2010; Mebratu, 2015). Notwithstanding this emerging interest, in internal audit quality (Neu, et al., 2013; Roussy, 2013; Vinnari \& Skaebaek, 2014), not much attention has as yet been focused on the role of competence \& staffing as a key internal audit function quality dimension, in fostering public sector transparency and accountability in developing economies (Mihret \& Yismaw, 2007; Yee, et al., 2008; Hutchinson \& Zain, 2009; Endaya \& Hanefah, 2013). In particular, none of the previous studies has been conducted in the context of Zimbabwe local government sub-sector. This study is meant to make an important contribution towards filling that void by attempting to analyse the impact of professional competence and staffing on transparency and accountability in Zimbabwe local authorities. 


\section{Literature review}

\subsection{The theory of inspired confidence}

The theory which is also referred to as the theory of rational expectations was developed by Theodore Limperg during the 1920s (Hayes et al, 2005). It asserts that the need for audit is driven by the involvement of external stakeholders in the affairs of the organisation. Stakeholders who contribute resources towards the existence and survival of the organisation demand accountability from those responsible for administering the day to day operations of the organisation. There is an inherent risk that the information about the affairs of the organisation availed by management might not honestly present the state of affairs, due to possible conflicting interests between management and stakeholders, hence such information should be subjected to some independent scrutiny. During such independent check, the auditor should use all the resources at his disposal to ensure that the expectations of stakeholders are met through provision of an expected level of assurance (Carmichael, 2004). The theory of inspired confidence explains the faith that the society has in the ability of the auditor to positively impact on reliability of information from management (Limperg institute, 1985), thus fostering quality accountability. Limperg describing the auditor's responsibility asserts; "The auditor-confidential agent derives his general function in society from the need for an expert and independent examination and the need for expert and independent opinion based on that examination. The function is rooted in the confidence society places in the effectiveness of the audit and the opinion of the accountant. This confidence is consequently a condition for the existence of that function; if the confidence is betrayed, the function too is destroyed, since it becomes useless". The theory emphasise on the need for an auditor, when confronted with a situation, to be always on the look for societal expectations aroused as a result, and act judiciously to the satisfaction of such expectation in order to retain confidence (Carmichael, 2004). Changes in the expectation of society also call for a change in the auditor's role and approach to his work, hence that explains the changes in an audit function attributes.

Though not widely used in internal auditing literature, the theory of inspired confidence helps in understanding how internal auditors' practices are impacted by the environment. Internal auditors make use of their understanding of social relationships and societal expectations to align their objectives to those of the organisation. This notion is supported by findings from a survey by Holt \&DeZoort (2009), which confirm that external stakeholders' confidence in company financial statements is determined by their perceived quality of the firm's internal audit function (Holt \& DeZoort, 2009). The theory of inspired confidence by emphasising the need for internal auditors to meet the rational expectations of stakeholders through the provision of internal assurance based on their work, failure of which creates an expectation gap (Ateya \& Kukreja, 2015), supports the possible existence of a positive relationship between internal audit function professional competency \& staffing and transparent accountability.

\subsection{Internal audit function professional competence and staffing}

Professional competency as defined by the Global Internal Audit Competency Framework can be referred to as "the ability of an individual to perform a job or a task properly". Competence is referred to a set defined knowledge, skills and behavior. A number of empirical studies on internal audit quality identified professional competency \& stuffing as a measure of internal audit function quality, ascertaining the measures of professional competency as commonly being based on experience, education, certification and training (Prawitt, et al., 2009; Lin, et al., 2011; Pizzini, et al., 2012). Hutchinson \& Zain (2009) investigated the relationship between internal audit function competency characteristics of experience and qualification and organization performance in Malaysia. The study established the existence of a pronounced relationship between qualification of internal auditors and firm performance (Hutchinson \& Zain, 2009). In a related study by Prawitt et al (2009) explored the relationship between internal audit quality and earnings management, quality being determined by experience and qualification, established the existence of a strong relationship between qualification of internal audit personnel and earnings management (Prawitt, et al., 2009).

Al-Matari et al 2014 further examined the association between various internal audit function competency characteristics such as qualifications of the chief audit executive, size, experience and qualification of the internal audit and firm performance. The study concluded that an internal audit is an important pillar in the corporate governance structure of an organization (Al-Matari, et al., 2014). The study noted a lack of research regarding the relationship between internal audit and organizational performance, in the context of both developing and developed nations. It went on to recommend the need for further empirical investigations into the relationship between internal audit and firm performance (Al-Matari, et al., 2014). In line with the findings, Abuazza et al (2015) conducted a study into the scope of internal audit functions in Libyan Public Sector. The study established that internal audit tasks were mainly centered on financial accounting matters, hence little focus and concentration on risk management and other governance issues (Abuazza, et al., 2015). This suggests lake of competencies within the public sector internal audit functions which is a hindrance to the full execution of the enhanced role of internal audit. The current study wishes to add on existing literature by exploring the impact of internal audit function competency and staffing on transparency and accountability in a developing nation's public sector, by its 
application to the Zimbabwe local governance subsector.

\subsection{Public finance management and internal audit model of Zimbabwe public sector.}

An assessment report of the Zimbabwe public finance management system by the World Bank (2015), revealed the need for the Zimbabwe public sector to improve its focus and attention on transparency and accountability. The report acknowledged the prevalence of rampant fraud and corruption in the public sector, notwithstanding enabling legal frameworks. Amongst the several weaknesses in the public finance management system, the report notes the weakness in the sector's internal audit function which is a result of, among other factors, inadequate skills and lack of competencies. This has been pointed as the reason behind the function's failure to attract credibility. The report recommended the need to improve skills and competencies of internal audit personnel as well as the establishment of a central unit or agency which oversees public sector internal audit, and carrying out its quality assurances. This recommendation is in line with the Ghanaian public sector internal audit model (Asare, 2009).

Ghana established an internal auditing agency in 2003; the Internal Audit Agency of Ghana was introduced as part of the public finance management reform program in an endeavor to enhance efficiency, transparency and accountability in the management of public sector resources (Asare, 2009; Onumah \& Yao Krah, 2015). The model applied in Zimbabwe particularly focusing on line ministries, falls between and is partly identical to the one applied in Uganda, Zambia and Botswana, where internal audit is supervised by the office responsible for finance, this can be inferred from the notion that the office of the Accountant General in the Ministry of Finance and Economic Development had the responsibility of crafting and upholding the recently introduced Government of Zimbabwe Internal Audit Manual of 2017. The model also partially suites the one applied in Malta (Asare, 2009), where internal audit is a function of the supreme audit institution, this can be inferred from the fact that regardless of the government ministry or department, internal auditors report to the office of the Auditor General. As much as public sector internal audit is mentioned in a number of legislative pronouncements, including the Constitution of Zimbabwe (Amendment No 20), The Public Finance Management Act (22:19), and The Public Entities Corporate Governance Act (10:13), there is no specific legislative framework of internal audit in Zimbabwe public sector. It can also be noted that there is no coordinated approach of internal auditing between the line ministries and local authorities, and also amongst local authorities in Zimbabwe.

\section{Conceptual Framework}

The conceptual framework was developed from a critical analysis of previous studies on internal audit and organizational performance. The current study is motivated from prior studies which point to the positive role played by a competent internal audit function in influencing organizational governance processes and practices. As such, the study hypothesizes that professional competence and staffing of an internal audit function is positively associated with improved transparency and accountability. The relationship between the independent variable, professional competence \& staffing and the dependent variable, transparency and accountability is illustrated in Fig 1 below;

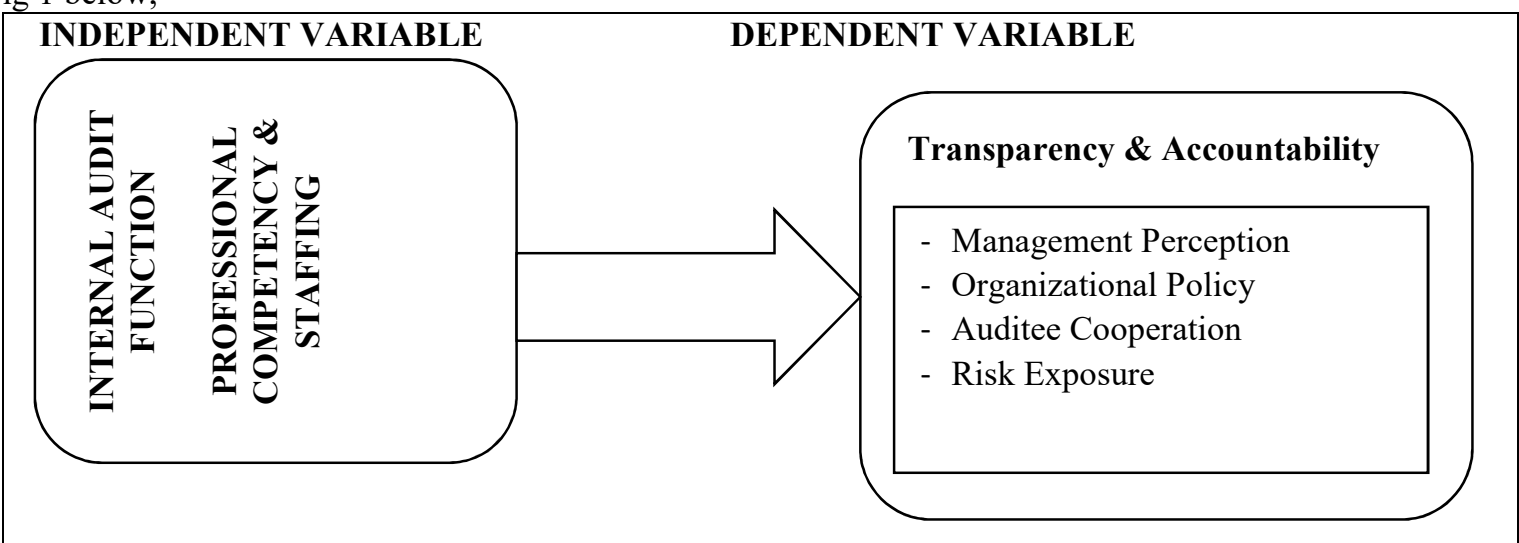

Figure 1: Study Conceptual Framework

Source: Researcher conceptualization, 2019

\subsection{Independent variable}

4.1.1. Measuring the independent variable - Professional Competence and Staffing

Professional competence \& staffing as an internal audit function quality dimension will be assessed using internal audit practitioners' views on specific items pertaining to experience (Mihret, et al., 2010; Al-Matari, et al., 2014), qualification (Hutchinson \& Zain, 2009), trainings and membership with the Institute of Internal Auditors (Jiang, et al., 2014; Al-Matari, et al., 2014). The table below summaries measures of the independent variable. 
Table 1: Independent Variable Measures

\begin{tabular}{|l|l|l|}
\hline Variable & Measurement & Reference \\
\hline Professional & Experience & Al-Matari et al, (2014) \\
\cline { 2 - 3 } $\begin{array}{l}\text { Competence and } \\
\text { Staffing }\end{array}$ & Qualification & Hutchson\& Zain, (2009); Al-Matari et al, (2014) \\
\cline { 2 - 2 } & Training & Jiang et al, (2014); Al-Matari et al, (2014); \\
\cline { 2 - 2 } & $\begin{array}{l}\text { Membership with the Institute of } \\
\text { Internal Auditors }\end{array}$ & \\
\hline
\end{tabular}

Source: Researcher, 2019

Semi-structured questionnaires will be used for the assessment, measured on a 5-point Likert-type scale ranging from "Strongly Agree" to "Strongly Disagree" or "Always" to "Never" depending on the nature of the items for each dimension. Internal audit practitioners (both the chief audit executive and internal audit staff) will be asked to indicate their opinions about professional competence and staffing of internal audit functions within their respective local authorities. Focus group discussions will also be contacted to gather data on how management and fellow internal audit practitioners view the competent nature of internal audit functions and their capacity to impact transparency and accountability in their respective local authorities.

\subsection{Measuring internal audit effectiveness in enhancing transparency and accountability}

Internal audit effectiveness in enhancing transparency and accountability for the purpose of this study will be assessed through a 5-point Likert-type scaled questionnaire and a focus group discussion on management's perceptions on specific issues about internal auditors' role within their respective local authorities. The questionnaire will also assess the extent to which management implement internal audit recommendations. Literature points to the difficulties of measuring internal audit effectiveness in upholding governance processes and the absence of a generally agreed approach for measurement (Arena \& Azzone, 2009; Noble, 2010; Erasmus \& Coetzee, 2018). However, as Arena and Azzone (2009) pointed out, the use of internal audit recommendation by management as an outcome measure (Roussy \& Brivot, 2016; Erasmus \& Coetzee, 2018) and the level of implementation of internal audit recommendations can be used as some of the objective measures of internal audit effectiveness (Sawyer, 1995; Van Gansberhe, 2005; Mihret \& Yismaw, 2007; Arena \& Azzone, 2009). The use and level of application of audit recommendation reflects on management support of the internal audit function. Internal audit literature points to the criticalness of management support in determining effectiveness of internal audit functions (Gramlin, et al., 2004; Sarens \& De Beelde, 2006a; Mihret \& Yismaw, 2007; Christopher, et al., 2009; Halimah, et al., 2009; Cohen \& Sayag, 2010).Management perceptions on internal auditor's role in transparency and accountability will be sought in terms of perceived risk exposure and management's action on internal audit recommendations (Cooper, et al., 1994; Arena \& Azzone, 2009; Mihret, et al., 2010; Aziz, 2013)

\section{Research methodology}

The study adopted a mixed methodology approach for data collection, making use of semi-structured questionnaires and focus group discussions. Focus group discussions were used to collect qualitative data as they are capable of giving results similar to those from semi-structured and group interviews (Parker \& Tritter, 2006). A documentary review of published literature on internal audit and corporate governance, policy documents and Zimbabwean legislation was also conducted. This concurrent triangulation method adopted allows the separate use of quantitative data obtained through questionnaires and qualitative data from focus group discussions to corroborate findings (Molina-Azori \& Cameron, 2010), as a means of counter balancing limitations of either the quantitative or qualitative methods of gathering data (Mihret \& Yismaw, 2007; Asare, 2009). Equal priority was therefore given to both results. There has been growing use of mixed research methods in related internal audit studies lately (Alleyne, et al., 2006; Onumah \& Yao Krah, 2015). Two focus group discussions were separately held on two different occasions to gain an in-depth understanding of the nature of internal audit function competencies and their perceived effects on transparency and accountability, and also to confirm quantitative results obtained through questionnaires. The focus group discussions aimed at obtaining data from senior management and Chief Audit Executives, drawing from their complex personal experiences, beliefs, perceptions and attitudes through a moderated interaction (Parker \& Tritter, 2006). During the focus group discussions, the researcher adopts the role of a facilitator and moderator, in an endeavor to minimize and eliminate researcher bias, unlike during interviews, the researcher took a peripheral, rather than a center stage role during the discussions (Bloor, et al., 2001). Four sets of data collection instruments were employed as depicted in the table below: 
Table 2: Data Collection Instruments

\begin{tabular}{|l|l|l|}
\hline Instrument set & Instrument form & Targeted class of respondents \\
\hline Instrument set (i) & Questionnaire & $\begin{array}{l}\text { Internal Audit Practitioners(Chief Audit Executives and } \\
\text { Audit Staff) }\end{array}$ \\
\hline $\begin{array}{l}\text { Instrument set } \\
\text { (ii) }\end{array}$ & Questionnaire & Senior Management \\
\hline $\begin{array}{l}\text { Instrument set } \\
\text { (iii) }\end{array}$ & $\begin{array}{l}\text { Focus group discussion } \\
\text { guide }\end{array}$ & Senior Management and Chief Audit Executives \\
\hline $\begin{array}{l}\text { Instrument set } \\
\text { (iv) }\end{array}$ & Document review guide & Secondary Data \\
\hline
\end{tabular}

Source: Researcher, 2019

Instrument set (i) is a questionnaire for internal audit personnel. Items are grouped under subheadings to assist participants gain easy grasp of questions being asked (Zikmund, 2003). Under the first part, perceptions were sought about organization policy, auditees' cooperation and risk exposure of their respective organizations. In the second part, participants were asked about their perception towards their functions' competencies \& staffing. The final part contains questions on the respondents' profile. Instrument set (ii) is a questionnaire for collecting data on the views and perceptions of management on the role of internal audit in promoting transparency and accountability. Management's views can provide a better picture on corporate governance and internal audit practices and influences thereof (Cooper, et al., 1994). To this end, this questionnaire was aimed at obtaining the views and opinions of senior management on some aspects of internal audit practice and its influence on transparency and accountability. Management's views instead, as opposed to those of councilors who happen to be the policy makers were used for the purpose of this study. This is because management is responsible for the day to day operations of local authorities.

Management personnel possess knowledge of several dimensions of corporate governance due to the nature of their jobs, and internal audit operations due to their close working relationships with internal auditors. The councilors on the other hand represent board members who are appointment based on political merit and not on academic or professional competency (Kurebwa, 2015). As such, poor judgment and their lack of knowledge concerning corporate governance issues cannot be ruled out. Councilors by nature are not fulltime employees of the local authorities, their main role is to provide interface between the local authority and the communities they serve, performing policy overview and scrutiny, executive decision making, providing political leadership, determining planning implications and community representation. As such, they may lack requisite knowledge of internal audit operations. Therefore, the use of management personnel's views in this study helped in generating relevant data which is within the scope of research objectives. Instrument set (iii) is a focus group discussion guide containing questions that were employed to collect data from senior management and Chief Audit Executives about their perspectives on the impact of internal audit function competence and staffing on impacting transparency and accountability within their respective local authorities. Instrument set (iv) is a document review checklist that guided the gathering of secondary data from various documentary sources. It specifies the documents reviewed and objectives of the review.

\subsection{Research Hypothesis}

The study hypothesis was formulated on the basis of the International Professional Practice Framework's code of ethics observed by internal audit practitioners. The code of ethics specifically requires internal audit practitioners to display professional competency through engaging only in those services for which they have necessary knowledge, skills and experience, and to continuously improve their proficiency and effectiveness (IIA, 2016). Literature which notes the need for Chief Audit Executives to ensure their internal audit functions are well staffed with the right mix of expertise, experience and qualifications so that they can fulfil their enhanced role scope also support the basis of this enquiry. As such, it aims to establish the relationship between internal audit function professional competence \& staffing and corporate governance. Quite a handful of empirical studies on internal audit quality consented to the notion that internal audit competency can be appraised through the function's characteristics of experience, education, certification and training (Prawitt, et al., 2009; Lin, et al., 2011; Pizzini, et al., 2012). Studies also reveal the existence of a competent internal audit function as having a positive impact on corporate governance practices as reflected through organizational performance (Hutchinson \& Zain, 2009; Prawitt, et al., 2009; Al-Matari, et al., 2014). To assess the association between internal audit professional competence \& staffing and corporate governance in Zimbabwe local authorities, using related variable measures as explained above, the hypothesis can be stated as:

\section{H3: Internal audit function professional competence \& staffing is positively associated with transparency} and accountability.

Hypothesis three has other four sub-hypothesis stated here under:

$\mathrm{H}_{\mathrm{a}}$ : Internal audit function professional competence \& staffing positively influences management perception 
towards internal auditors' capacity to impact on corporate governance practices.

$\mathrm{H} 3_{\mathrm{b}}$ : Internal audit function professional competence \& staffing is positively associated with the existence of an organization policy authorizing internal audit.

$\mathrm{H} 3_{\mathrm{c}}$ : Internal audit function professional competence \& staffing is positively associated with management cooperation.

$\mathrm{H} 3{ }_{\mathrm{d}}$ : The existence of a professionally competent and well-staffed internal audit function is positively associated with the extent to which an organization is safeguarded against risk exposure.

\section{Research findings}

\subsection{Source of research data}

Data for the current study was obtained from a sample of 182 senior management and internal audit personnel from Zimbabwe local authorities through semi-structured questionnaires and focus group discussions. Table 3 below shows the source of questionnaire respondents and their percentage representation. A greater representation of participants was from Rural District Councils, representing $60.99 \%$ of participants. The level of participation is representative as it was relative to the pro-rated distribution of questionnaires. In Zimbabwe there are 92 local authorities, categorized in to 60 Rural District Councils (RDCs), 7 City Councils, 8 Municipalities, 13 Town Councils and 4 Local Boards. As such, the sample of the study is capable of yielding results which are representative of the population and therefore findings can be deemed reliable.

Table 3: Categorization and representation of questionnaire respondents

\begin{tabular}{|l|c|c|}
\hline Local Authority Status & Participants & Distributed \\
\hline City Council & $18(9.89 \%)$ & $21(7.78 \%)$ \\
\hline Municipality & $21(11.54 \%)$ & $24(8.89 \%)$ \\
\hline Town Council & $20(10.99 \%)$ & $33(12.22 \%)$ \\
\hline Local Board & $12(6.59 \%)$ & $12(4.44 \%)$ \\
\hline Rural District Council & $111(60.99 \%)$ & $180(66.67 \%)$ \\
\hline
\end{tabular}

Source: Researcher, 2019

Two focus group discussion were conducted on two different occasions. Participants for the first focus group discussion were senior managers, 13 members were selected at a Chart of Accounts workshop facilitated by the Ministry of Local Government Public Works and National Housing's Financial Advisory Department, held at Fairmile Hotel in Gweru, Zimbabwe from the $11^{\text {th }}$ to the $15^{\text {th }}$ of February 2019. In attendance at the workshop were all rural local authorities' treasurers, all urban local authorities finance directors, the ministry's financial advisory personnel and accounting software developers. The second focus group discussion was composed of 8 Chief Audit Executives selected at the Institute of Internal Auditors (Zimbabwe), Audit Committee workshop help at Golden Peacock Villa Hotel in Mutare, Zimbabwe from the $12^{\text {th }}$ to the $15^{\text {th }}$ of March 2019. In attendance at the workshop were Chief Audit Executives, Internal Auditors, Audit committee members and Council executives. Literature notes that number of participants in a focus group discussion is an important factor in determining the quality of output, recommending between six and eight participants (Krueger \& Casey, 2000), however other studies have reported as few as four and as many as fifteen participants (Parker \& Tritter, 2006).

\subsection{Reliability and validity}

The current study used items measured on a Likert scale; therefore, reliability was assessed using Cronbach's Alpha to assess internal consistency. Table 4 below shows the overall Cronbach's Alpha of 0.891 which is above the recommended threshold of 0.7 . This generally renders the instrument reliable for the study.

Table 4: Reliability Statistics

\begin{tabular}{|c|c|c|}
\hline \multicolumn{2}{|l|}{ Reliability Statistics } & N of Items \\
\hline Cronbach's Alpha & Cronbach's Alpha Based on Standardized Items & 45 \\
\hline 0.891 & 0.924 & \\
\hline
\end{tabular}

Source: Researcher, 2019

\subsection{Hypothesis testing}

We taste the relationship between professional competence \& staffing and transparency \& accountability by using regression and multivariate analysis. We re-stated the hypothesis here under:

\section{H3: Internal audit function professional competence \& staffing is negatively associated with transparency} and accountability.

We also test the sub-hypotheses re-stated here under:

$\mathrm{H}_{\mathrm{a}}$ : Internal audit function professional competence \& staffing negatively influences management perception towards internal auditors' capacity to impact on corporate governance practices.

$\mathrm{H} 3_{\mathrm{b}}$ : Internal audit function professional competence \& staffing is negatively associated with the existence of an 
organization policy authorizing internal audit.

$\mathrm{H} 3_{\mathrm{c}}$ : Internal audit function professional competence \& staffing is negatively associated with management cooperation.

$\mathrm{H} 3_{\mathrm{d}}$ : The existence of a professionally competent and well-staffed internal audit function is negatively associated with the extent to which an organization is safeguarded against risk exposure.

\subsubsection{Regression Analysis}

Table 5 below shows ANOVA results for professional competence \& staffing with a p-value of 0.01 . The p-value being significant at 0.05 , helps us to conclude that professional competence \& staffing of an internal audit function significantly explains how management perceives internal auditors' capacity to impact corporate governance practices.

Table 5: ANOVA - Professional Competence \& Staffing and Management Perception

\begin{tabular}{|c|c|c|c|c|c|c|}
\hline \multicolumn{7}{|c|}{ ANOVA } \\
\hline \multicolumn{2}{|c|}{ Model } & Sum of Squares & Df & Mean Square & F & Sig. \\
\hline \multirow[t]{3}{*}{1} & Regression & 7.168 & 3 & 2.389 & .036 & $.001^{\mathrm{b}}$ \\
\hline & Residual & 14157.974 & 214 & 66.159 & & \\
\hline & Total & 14165.142 & 217 & & & \\
\hline \multicolumn{7}{|c|}{ a. Dependent Variable: Management perspective } \\
\hline \multicolumn{7}{|c|}{ b. Predictors: (Constant), Training, Staffing, Qualification and Experience } \\
\hline
\end{tabular}

Source: Researcher, 2019

Table 6 shows internal audit function competency dimensions of qualification \& experience with a positive result (Beta 0.35) and training also with a positive result (Beta 0.81). These results are significant at 0.05 , meaning that internal audit function professional competency as driven by qualification \& experience and training positively influences the way management perceive internal auditors' capacity to impact corporate governance practices. This therefore leads us to the conclusion of rejecting the null sub-hypothesis $\left(\mathrm{H} 3_{\mathrm{a}}\right)$ that internal audit function professional competence \& staffing negatively influences management perception towards internal auditors' capacity to impact on corporate governance practices.

Table 6: Regression - Professional Competence \& Staffing and Management Perception

\begin{tabular}{|c|c|c|c|c|c|c|}
\hline & & & Coefficients & & & \\
\hline & & Unstandard & Coefficients & Standardized & $\mathrm{t}$ & Sig. \\
\hline & & B & Std. Error & Beta & & \\
\hline 1 & (Constant) & 99.027 & 4.444 & & 22.285 & .000 \\
\hline & Staffing & .041 & .417 & .008 & .098 & .922 \\
\hline & $\begin{array}{l}\text { Qualification and } \\
\text { Experience }\end{array}$ & .035 & .357 & .008 & .099 & .021 \\
\hline & Training & .081 & .340 & .019 & .238 & .012 \\
\hline
\end{tabular}

a. Dependent Variable: Management perspective

Source: Researcher, 2019

Table 7 below shows ANOVA results for professional competency \& staffing, with a p-value of 0.036 . The p-value is significant at 0.05 , helping us to conclude that professional competency and staffing of an internal audit function significantly explains the existence of an organization policy authorizing internal audit.

Table 7: ANOVA - Professional Competence \& Staffing and Organization Policy

\begin{tabular}{|l|l|r|r|r|r|c|}
\hline \multicolumn{9}{|c|}{ ANOVA $^{\mathbf{a}}$} & \multicolumn{1}{c|}{ Sig. } \\
\hline \multicolumn{2}{|c|}{ Model } & Sum of Squares & df & Mean Square & \multicolumn{1}{c|}{ F } & Sig. \\
\hline \multirow{3}{*}{1} & Regression & 6.977 & 3 & 2.326 & .569 & $.036^{\text {b }}$ \\
\cline { 2 - 8 } & Residual & 874.527 & 214 & 4.087 & & \\
\cline { 2 - 8 } & Total & 881.505 & 217 & & \\
\hline
\end{tabular}

a. Dependent Variable: Organizational policy

b. Predictors: (Constant), Training, Staffing, Qualification and Experience

Source: Researcher, 2019

Results on table 8 below shows internal audit function competency dimension of qualification \& experience with a positive result (Beta 0.047 ), being significant at 0.05 , meaning that internal audit function professional competency as determined by internal auditors' qualifications \& experience positively influences the existence of an organizational policy authorizing internal audit. This leads to the conclusion of rejecting the null sub-hypothesis $\left(\mathrm{H} 3_{\mathrm{b}}\right)$ that internal audit function professional competence \& staffing is negatively associated with the existence of an organization policy authorizing internal audit. However, the results also show that training as an internal audit function competency dimension with a negative result (Beta -0.075) which is significant at 0.05 negatively impacts the existence of an organization policy authorizing internal audit. 
Table 8: Regression - Professional Competency \& Staffing and Organization Policy

\begin{tabular}{|c|c|c|c|c|c|c|}
\hline & & $\mathrm{Co}$ & icients & & & \\
\hline & & $\begin{array}{r}\text { Unstan } \\
\text { Coef }\end{array}$ & $\begin{array}{l}\text { dized } \\
\text { ents }\end{array}$ & $\begin{array}{l}\text { Standardized } \\
\text { Coefficients }\end{array}$ & $\mathrm{t}$ & Sig. \\
\hline & & $\mathrm{B}$ & Std. Error & Beta & & \\
\hline 1 & (Constant) & 18.708 & 1.104 & & 16.940 & .000 \\
\hline & Staffing & -.083 & .104 & -.062 & -.802 & .423 \\
\hline & $\begin{array}{ll}\text { Qualification } & \text { and } \\
\text { Experience } & \end{array}$ & .047 & .089 & .045 & .527 & .009 \\
\hline & Training & -.075 & .084 & -.071 & -.893 & .003 \\
\hline
\end{tabular}

Source: Researcher, 2019

Table 9 below shows ANOVA results for internal audit function professional competence \& staffing with a p-value of 0.01 . This result being significant at 0.05 , help us to conclude that professional competence $\&$ staffing account for the extent to which management cooperate with internal auditors.

Table 9: ANOVA - Professional Competence \& Staffing and Auditee Cooperation

\begin{tabular}{|l|l|r|r|r|c|c|}
\hline \multicolumn{7}{|c|}{ ANOVA $^{\mathbf{a}}$} \\
\hline \multicolumn{2}{|c|}{ Model } & Sum of Squares & df & Mean Square & F & Sig. \\
\hline \multirow{3}{*}{1} & Regression & 7.320 & 3 & 2.440 & 1.028 & $.001^{\text {b }}$ \\
\cline { 2 - 7 } & Residual & 507.891 & 214 & 2.373 & & \\
\cline { 2 - 7 } & Total & 515.211 & 217 & & & \\
\hline
\end{tabular}

a. Dependent Variable: Auditee Cooperation

b. Predictors: (Constant), Training, Staffing, Qualification and Experience

Source: Researcher, 2019

Regression results (Table 10) indicate internal audit function professional competence and staffing dimensions with positive results for staffing (Beta .121), qualification \& experience (Beta 0.54) and training (Beta 0.043 ), all being significant at 0.05 . This means that internal audit function professional competence $\&$ staffing is positively associated with auditees cooperation. This leads us to the conclusion of rejecting the null sub-hypothesis $\left(\mathrm{H} 3_{\mathrm{c}}\right)$ that internal audit function professional competence \& staffing is negatively associated with management cooperation.

Table 10: Regression - Professional Competence \& Staffing and Auditee Cooperation

\begin{tabular}{|c|c|c|c|c|c|c|}
\hline & & & oefficients & & & \\
\hline & & $\begin{array}{r}\mathrm{Uns} \\
\mathrm{Cc}\end{array}$ & $\begin{array}{l}\text { lardized } \\
\text { cients }\end{array}$ & $\begin{array}{l}\text { Standardized } \\
\text { Coefficients }\end{array}$ & $\mathrm{t}$ & Sig. \\
\hline & & B & Std. Error & Beta & & \\
\hline 1 & (Constant) & 14.143 & .842 & & 16.804 & .000 \\
\hline & Staffing & .121 & .079 & .118 & 1.529 & .028 \\
\hline & $\begin{array}{ll}\text { Qualification } & \text { and } \\
\text { Experience } & \end{array}$ & .054 & .068 & .068 & .798 & .006 \\
\hline & Training & .043 & .064 & .053 & .665 & .007 \\
\hline
\end{tabular}

Source: Researcher, 2019

Table 11 below shows ANOVA results for internal audit function professional competence \& staffing having a p-value 0.03 which is significant at 0.05 , helping us to conclude that internal audit function professional competence and staffing can be used to explain the extent to which an organization is safeguarded against risk exposure.

Table 11: ANOVA - Professional Competence \& Staffing and Risk Exposure

\begin{tabular}{|c|c|c|c|c|c|c|}
\hline \multicolumn{7}{|c|}{ ANOVA $^{a}$} \\
\hline \multicolumn{2}{|c|}{ Model } & Sum of Squares & df & Mean & $\mathrm{F}$ & Sig. \\
\hline \multirow[t]{3}{*}{1} & Regression & 29.952 & 3 & 9.984 & 1.002 & $.003^{\mathrm{b}}$ \\
\hline & Residual & 2133.259 & 214 & 9.968 & & \\
\hline & Total & 2163.211 & 217 & & & \\
\hline \multicolumn{7}{|c|}{ a. Dependent Variable: Risk Exposure } \\
\hline
\end{tabular}

Source: Researcher, 2019

An analysis of table 12 below reflects that internal audit function professional competence and staffing as 
driven by staffing and competency dimension of qualification \& experience have positive results; staffing (Beta 0.155 ) and qualification \& experiences (Beta 0.107), which are significant at 0.05 . This means that internal audit function professional competence and staffing as determined by staffing and internal auditors' qualifications \& experience dimensions impacts the extent to which an organization is safeguarded against risk exposure. This leads us to the conclusion of rejecting the null sub-hypothesis $\left(\mathrm{H} 3_{\mathrm{d}}\right)$ that the existence of a professionally competent and well-staffed internal audit function is negatively associated with the extent to which an organization is safeguarded against risk exposure.

Table 12: Regression - Professional Competence \& staffing and Risk Exposure

\begin{tabular}{|c|c|c|c|c|c|c|}
\hline & & & ients & & & \\
\hline & & & $\begin{array}{l}\text { dardized } \\
\text { icients }\end{array}$ & $\begin{array}{l}\text { Standardized } \\
\text { Coefficients }\end{array}$ & $\mathrm{t}$ & Sig. \\
\hline & & B & Std. Error & Beta & & \\
\hline 1 & (Constant) & 20.066 & 1.725 & & 11.633 & .000 \\
\hline & Staffing & .155 & .162 & .074 & .959 & .033 \\
\hline & Qualification and Experience & .107 & .138 & .066 & .775 & .043 \\
\hline & Training & -.185 & .132 & -.111 & -1.400 & .163 \\
\hline
\end{tabular}

a. Dependent Variable: Risk Exposure

Source: Researcher, 2019

\subsubsection{Multivariate Analysis}

Table 13 below illustrate the multivariate analysis results for the Pillai's trace and other three multivariate statistics, Wilks' Lambda, Hotelling's trace and Roy's largest root. The Pillai's Trace is a positive valid statistic ranging from 0 to 1 . Increasing values means that the effects are contributing more to the model, leading to the conclusion of rejecting the null hypothesis. The Pillai's Trace statistic is generally considered the most powerful statistic. From the multivariate analysis results which reflects the contribution of the independent variable and the related dimensions to the dependent variable (Table 13), it can be deduced that in terms of equality of contribution, internal auditors' qualifications \& experience and training significantly contribute to determining transparency and accountability in Zimbabwe local authorities, as compared to the effect of staffing. This leads us to the conclusion of rejecting the null hypothesis (H3) that internal audit function professional competence \& staffing is negatively associated with transparency $\&$ accountability. When considering ways to enhance transparency and accountability in Zimbabwe local authorities, focus should be on competency dimensions of qualification \& experience and training which are more relevant as compared to staffing.

Table 13: Multivariate Analysis - Professional Competence \& Staffing and Transparency \& Accountability

\begin{tabular}{|c|c|c|c|c|c|c|}
\hline \multicolumn{7}{|l|}{ Multivariate Testsa } \\
\hline Effect & & Value & $\mathrm{F}$ & Hypothesis df & Error df & Sig. \\
\hline \multirow[t]{4}{*}{ Intercept } & Pillai's Trace & 0.981 & $2027.870 \mathrm{~b}$ & 3 & 120 & 0.000 \\
\hline & Wilks' Lambda & 0.019 & $2027.870 \mathrm{~b}$ & 3 & 120 & 0.000 \\
\hline & Hotelling's Trace & 50.697 & $2027.870 \mathrm{~b}$ & 3 & 120 & 0.000 \\
\hline & Roy's Largest Root & 50.697 & $2027.870 \mathrm{~b}$ & 3 & 120 & 0.000 \\
\hline \multirow[t]{4}{*}{ Staffing } & Pillai's Trace & 0.212 & 1.327 & 21 & 366 & 0.153 \\
\hline & Wilks' Lambda & 0.797 & 1.348 & 21 & 345.125 & 0.142 \\
\hline & Hotelling's Trace & 0.242 & 1.367 & 21 & 356 & 0.131 \\
\hline & Roy's Largest Root & 0.181 & $3.153 \mathrm{c}$ & 7 & 122 & 0.004 \\
\hline \multirow[t]{4}{*}{ Qualification and Experience } & Pillai's Trace & 0.306 & 1.978 & 21 & 366 & 0.007 \\
\hline & Wilks' Lambda & 0.717 & 2.022 & 21 & 345.125 & 0.005 \\
\hline & Hotelling's Trace & 0.365 & 2.06 & 21 & 356 & 0.004 \\
\hline & Roy's Largest Root & 0.251 & $4.370 \mathrm{c}$ & 7 & 122 & 0.000 \\
\hline \multirow[t]{4}{*}{ Training } & Pillai's Trace & 0.493 & 3.001 & 24 & 366 & 0.000 \\
\hline & Wilks' Lambda & 0.553 & 3.29 & 24 & 348.638 & 0.000 \\
\hline & Hotelling's Trace & 0.726 & 3.59 & 24 & 356 & 0.000 \\
\hline & Roy's Largest Root & 0.6 & $9.155 \mathrm{c}$ & 8 & 122 & 0.000 \\
\hline
\end{tabular}

a Design: Intercept + Staffing + Qualification and Experience + Training + Staffing * Qualification and Experience

\section{b Exact statistic}

c The statistic is an upper bound on $\mathrm{F}$ that yields a lower bound on the significance level.

Source: Researcher, 2019

This relationship is also confirmed by the Test of Between-Subjects Effects (Table 14), which confirms that training and qualification \& experience dimensions of internal audit function competency dominantly determine the extent of transparency and accountability in Zimbabwe local authorities. 
Table 14: Tests of Between-Subjects Effects

\begin{tabular}{|c|c|c|c|c|c|c|}
\hline \multicolumn{7}{|c|}{ Tests of Between-Subjects Effects } \\
\hline Source & Dependent Variable & $\begin{array}{l}\text { Type III Sum of } \\
\text { Squares }\end{array}$ & df & $\begin{array}{l}\text { Mean } \\
\text { Square }\end{array}$ & $\mathrm{F}$ & Sig. \\
\hline \multirow{3}{*}{$\begin{array}{l}\text { Corrected } \\
\text { Model }\end{array}$} & Organizational policy & $510.857 \mathrm{a}$ & 95 & 5.377 & 1.77 & 0.002 \\
\hline & Auditee Cooperation & $278.684 b$ & 95 & 2.934 & 1.513 & 0.016 \\
\hline & Risk Exposure & $1061.239 \mathrm{c}$ & 95 & 11.171 & 1.237 & 0.134 \\
\hline \multirow[t]{3}{*}{ Intercept } & Organizational policy & 14979.45 & 1 & 14979.45 & 4930.545 & 0.000 \\
\hline & Auditee Cooperation & 8258.834 & 1 & 8258.834 & 4259.886 & 0.000 \\
\hline & Risk Exposure & 19242.03 & 1 & 19242.03 & 2130.297 & 0.000 \\
\hline \multirow[t]{3}{*}{ Staffing } & Organizational policy & 18.975 & 7 & 2.711 & 0.892 & 0.515 \\
\hline & Auditee Cooperation & 22.106 & 7 & 3.158 & 1.629 & 0.133 \\
\hline & Risk Exposure & 39.771 & 7 & 5.682 & 0.629 & 0.731 \\
\hline \multirow{3}{*}{$\begin{array}{l}\text { Qualification } \\
\text { and } \\
\text { Experience }\end{array}$} & Organizational policy & 91.248 & 7 & 13.035 & 4.291 & 0.000 \\
\hline & Auditee Cooperation & 37.538 & 7 & 5.363 & 2.766 & 0.011 \\
\hline & Risk Exposure & 56.401 & 7 & 8.057 & 0.892 & 0.515 \\
\hline \multirow[t]{3}{*}{ Training } & Organizational policy & 193.277 & 8 & 24.16 & 7.952 & 0.000 \\
\hline & Auditee Cooperation & 97.679 & 8 & 12.21 & 6.298 & 0.000 \\
\hline & Risk Exposure & 221.026 & 8 & 27.628 & 3.059 & 0.004 \\
\hline \multicolumn{7}{|c|}{ a R Squared $=.580($ Adjusted R Squared $=.252)$} \\
\hline \multicolumn{7}{|c|}{ b R Squared $=.541($ Adjusted R Squared $=.183)$} \\
\hline \multicolumn{7}{|c|}{ c R Squared $=.491($ Adjusted R Squared $=.094)$} \\
\hline
\end{tabular}

Source: Researcher, 2019

Focus group discussion results were in agreement with what has been establishment from statistical inferences that internal audit function professional competence and staffing factors influence the degree of transparency and accountability in Zimbabwe local authorities. However, the discussions revealed the existence of impediments against establishments of competent and well-staffed internal audit functions in Zimbabwe local authorities. Brainstorming on factors determining the effectiveness of their audit functions in influencing corporate governance practices, participants pointed to low levels of moral and esteem within internal auditors, which is a result of poor remuneration systems. It has been established that the grading system in a number of local authorities entails internal auditors are not fairly remunerated as compared to other management personnel. An example of a case raised is where a Chief Audit Executive at a rural district council being in grade 9, whereas fellow departmental heads such as the treasurer will be in grade 10. Lack of continuous professional development and training has also been pointed as another impediment on internal audit function effectiveness, particularly pertaining to information technology applications and infrastructure. This was blamed on lack of management support since other management departments engage more in professional development and training programs as compared to audit. Whenever an audit practitioner request for continuous professional development financing, management usually turn down the request noting lack of financial resources.

Chief Audit Executives pointed out that majority of their team members, including some of the fellow Chief Audit Executives do not have specific technical internal audit qualifications. Majority of them have accounting qualifications and designations, dominantly the Chattered and Certified Accountants (ACCA), the Certified Tax Accountants (CTA), the Certified Public Accountants (CPA) and the Chattered Institute of secretaries (CIS) designations. Local authorities in Zimbabwe when employing internal audit personnel equally consider an accounting qualified candidate as equally fit for internal auditing positions, hence these qualifications and designations are ranked equally. Practitioners also point to a problem associated with incompatibility of some duties and responsibilities assigned to fellow internal auditors. It was pointed that some local authorities require internal auditors to check on documentation and records on payment vouchers before payments are made and make an endorsement as proof of certifying the correctness of the record to ensure management comply with all the procurement and document authorisation requirements. This 'pre-audit' function entails internal audit functions appearing as an extension of the finance and accounting function of local authorities, and is associated with some self-review and familiarity threats. Chief Audit Executives also noted lack of support and coordination of internal audit activities by the Ministry of Local Government, Public Works and National Housing's internal audit function. The ministry's internal audit function is better positioned to enhance and further the effectiveness of local authorities' internal audit functions through complementing and coordinating their efforts. They reported ministry internal audit personnel as viewing themselves and acting as external auditors whereas in actual fact they are both internal auditors serving the same local government subsector, but at different levels of the sector's structure. It was noted that ministry internal audit personnel when they visit local authorities during special assignments they rarely consider opinions and contributions from resident internal auditors, who in a way are usually better informed 
about systems of their respective local authorities and the background of the phenomenon under review.

Brainstorming internal audit function capacity to help local authorities improve service delivery and attainment of objectives, senior management personnel blamed internal auditors for being unprofessional and operating like a policing section of the organisation. They described internal auditors in their respective local authorities as "counter-productive" and lacking requisite modern skills such as information technology skills. These sentiments clearly point to skills and competencies deficiency in Zimbabwe local authorities, and as such, this has an effect of negatively impacting on how management perceive internal audit function quality, hence determining the level of value placed upon internal audit findings and recommendations.

\section{Discussion}

The study findings established the existence of a statistically significant positive relationship between professional competency of an internal audit function represented by internal auditors' qualifications \& experience and availability of training opportunities and transparency and accountability in Zimbabwe local authorities. Local authorities in Zimbabwe therefore should address various factors noted as impediments to the establishment of competent internal audit functions in Zimbabwe local authorities. Study findings establish that internal audit personnel in local authorities have low morale and esteem levels as a result of a handful of factors, the dominant of them being poor remuneration levels relative to those of management personnel. This is a major setback considering that internal audit functions of local authorities should be given a relatively high status so as to enhance independence, evident recognition and enhance communication with top management. Literature supports that internal auditors are highly likely to be effective in executing their mandates and promoting good governance if the function is properly positioned and given a relatively high status within the local authority structures, as accountability is highly likely to materialise if requested form a position of authority (Steinbauer, et al., 2014; Pearson \& Sutherland, 2017).

Lack of technical internal audit qualifications, and affiliation with the Institute of Internal Auditors has also been noted as a major drawback and negatively affecting the competent nature of internal audit functions. It has been established that majority of internal auditors in local authorities lack technical internal audit qualifications and affiliation, as they have accounting qualifications and designations. This has an effect of negatively affecting the scope of internal audit functions as internal auditors will have more inclination and bias towards accounting checks and control, at the expense of critical governance, risk management and performance audit issues. This finding is in line with what has been established by Asare (2009), when he noted the same phenomenon in the Ghanaian Public Sector (Asare, 2009). This point to the notion that internal audit kills and competencies are lacking in developing nations. Another setback to effective competent execution of internal audit engagements concerns the involvement of internal auditors in pre-auditing of payment vouchers, which is associated with commensurate familiarity and self-review threats. These activities contravene internal audit international best practice requirements (IIA, 2016), thereby undermining the capacity of internal audit function to positively impact corporate governance practices. Results from the study also established lack of support from and coordination of local authorities' internal audit functions with the Ministry of Local Government, Public Works and National Housing's internal audit function. Coordinated efforts between these two internal audit functions in the local governance subsector is ideal for the improvement in the capacity of local authorities' internal audit functions to positively impact corporate governance practices. This coordination can be attained through establishing a centralised Local Government Internal Audit Agency, within the Ministry of Local Government, Public Works and National Housing to oversee, monitor, supervise and review internal audit functions within local authorities, taking lessons from the centralised public sector internal audit agency of the republic of Ghana (Asare, 2009; Onumah \& Yao Krah, 2015).

\section{Conclusion}

The study investigated the impact of professional competence and staffing of internal audit function on transparency and accountability in Zimbabwe local authorities. The study established that internal audit function professional competence dimensions of qualification \& experience and training positively influences transparency and accountability in Zimbabwe local authorities. However, the study established a handful of impediments to the competency and effectiveness of internal audit functions in Zimbabwe local authorities, including poor remuneration systems, lack of financial support for continuous professional development, performance of incompatible duties and lack of coordinated internal audit activities, functions and structures within the local government subsector. The study therefore recommends efforts be made to ensure structures are in place to safeguard and promote internal audit function competences in local authorities so as to enhance transparency and accountability. Suggested measures include the establishment by the government of Zimbabwe, through the Ministry of Local Government, Public Works and National Housing of a centralised Local Government Internal Audit Agency under the Ministry of Local Government, Public Works and National Housing, responsible for overseeing, monitoring, supervising and reviewing internal audit functions within local authorities so as to enhance 
coordination, and guaranteeing the functions' effectiveness, which in turn has potential benefits of improving public finance management systems and enhancing corporate governance practices in the entire local government subsector.

\section{References}

Abbott, L. J., Daugherty, B., Parker, S. \& Peters, G. F., 2016. Internal audit quality and financial reporting quality: The joint importance of independence and competence. Journal of Accounting research, 54(1), pp. 3-40.

Abu-Azza, W., 2012. Perceived effectiveness of the internal audit function in Lybia: a qualitative study using institutional and Marxist theories. s.1.:University of Southern Queensland.

Abuazza, W. O., Mihret, D. G. \& James, K., 2015. The perceived scope of internal audit function in Lybian Public enterprises. Managerial Auditing Journal, 30(67), pp. 560-581.

Adams, M. B., 1994. Agency theory and the internal audit. Managerial Auditing Journal, 9(8), pp. 8-12.

Alhajri, M. O., 2017. Factors associated with the size of internal audit fiunctions: Evidence from Kuwait. Managerial Auditing Journal, Vol. 32 Issue. 1, pp. 75-89.

Alleyne, P., Machael, H. \& Greenidge, D., 2006. The role of audit committees in Barbados. Corporate Governance, 6(5), pp. 567-581.

Al-Matari, E. M., Al-Swidi, A. K. \& Fadzil, H. F. B., 2014. The Effect of the Internal Audit and Firm Performance: A Proposed Reseach Framework. International Review of Management and Marketing, 4(1), pp. 34-41.

Al-Matari, E. M., Al-Swidi, A. K., Faudziah, H. B. \& Al-Matari, Y. A., 2012. The impact of board characteristics on firm performance: Evidence from nin-financial listed companies in Kuwaiti Stock Exchange. International Journal of Accounting and Financial reporting, 2(2), pp. 310-332.

Al-Shabail, A. M. \& Turki, A. A. T., 2017. A theoratical discussion of internal audit effectiveness in Kuwaiti Industrial SMEs. International Journal of Accademic Research in Accounting, Finance and Management Sciences, 7(1), pp. 107-116.

Al-Twaijry, A. A., Brierley, J. A. \& Gwilliam, D. R., 2003. The development of internal auditing in Saudi Arabia: An institutional theory perspective.. Critical Perspectives on Accounting, 14(5), pp. 507-531.

Alzeban, A. \& Gwilliam, D., 2014. Factors affecting the internal audit function effectiveness: A survey of Saudi public sector. Journal of Accounting, Auditing and Taxation, Vol. 23 No. 2, pp. 74-86.

Anderson, U., Christ, M., Johnstone, K. \& Rittenberg, L., 2012. A post-SOX examination of factors associated with the size of internal audit functions. Accounting Horizons, Vol. 26 No. 2, pp. 167-191.

Anon., n.d.

Arena, M. \& Azzone, G., 2009. Identifying organisational drivers of internal audit effectiveness. International Journal of Auditing, 13(1), pp. 43-60.

Arena, M. \& Azzone, G., 2009. Internal audit effectiveness: Relevant drivers of auditees' satisfaction. International Journal of Auditing, Vol. 13 No. 1, pp. 43-60.

Asare, T., 2009. Internal Auditing in the Public Sector: Promoting good governance and performance improvement.. International Journal on Governmental Financial Management, IX, pp. 15-27.

Ateya, M. G. \& Kukreja, G., 2015. Evaluating the perceptions of investment banks on the effectiveness of financial audit report: Evidence from Kingdom of Brahrain. International Journal of Management Studies \& Research, 3(7), pp. 20-30.

Aziz, N. A. A., 2013. Managing corporate risk and achieving internal control through statutory compliance. Journal of Financial Crime, 20(1), pp. 25-38.

Badara, M. S. \& Saidin, S. Z., 2013. The relationship between audit experience and internal audit effecticeness in the public sector organisations. International Journal of Academic Research in Accounting, Finance and Management Services, Vol. 3 No. 3, pp. 329-339.

Barua, A., Rama, D. \& Sharma, V., 2010. Audit committee characteristics and investment in internal auditing. Journal of Accounting and Public Policy, Vol.29 No. 5, pp. 503-513.

Bloor, M., Frankland, J., Thomas, M. \& Robson, K., 2001. Focus groups in social research. Thousand Oaks: Sage Publications.

Burbaby, P. \& Hass, S., 2009. A summary of the global Common Body of Knowledge 2006 (CBOK) study in internal auditing. Managerial Auditing Journal, 24(9), pp. 813-834.

Caplan, D. H. \& Kirschenheiter, M., 2000. Outsourcing and audit risk for internal audit services.. Contemporary Accounting Research, 17(3), pp. 387-428.

Carcello, J. V., Hermanson, D. \& Raghunandan, 2005. Factors associated with US Public companies investment in internal auditing. Accounting Horizons, Vol. 19 No. 2, pp. 69-84.

Carmichael, D. R., 2004. The PCAOB and the social responsibility of the auditor. Accounting Horizons, 18(2), pp. 127-133.

Caswell, B. \& Allen, C., 2001. The engagement team approarch to independence. Journal of Accountancy, 191(2), pp. 57-63. 
Chambers, A., 2008. The board's black hole- filling their assurance vacuum, can internal audit rise to the challenge. Measuring Business excellence, Vol.12 No. 1, pp. 47-63.

Chambers, R. F., 2014. Lessons learned on the AUDIT TRAIL, Altamonte Springs: The IIA Research Foundation.

Christopher, J., 2014. Internal Audit: Does it enhance governance in the Australian University Sector?. Education Management Aministration and Leadership, pp. 1-18.

Christopher, J., Sarens, G. \& Leung, P., 2009. A critical analysis of the independence of the internal audit function: Evidence from Australia. Accountung, Auditing and Accountability Journal, Vol. 22(2), pp. 200-220.

Christopher, J., Sarens, G. \& Leung, P., 2009. A critical analysis of the independence of the internal audit function: Evidence from Australia.. Accounting,Auditing and Accountability Journal, Vol 22 (2), pp. 200-220.

Cohen, A. \& Sayag, G., 2010. The effectiveness of internal auditing: An empirical examination of its determinants in Israeli organisations. Australian Accounting Review, pp. 296-307.

Cooper, B. J., Leung, P. \& Mathew, C., 1994. Internal audit: An Ausitralian profile. Managerial Auditing Journal, 9(3), pp. 13-19.

Dal Mas, L. O. \& Barac, K., 2018. The influence of the Chief Audit Executive's leadership style on factors related to internal audit effectiveness. Managerial Auditing Journal, Vol. 33 Issue. 8/9, pp. 805-835.

DeAngelo, L. E., 1981. Auditor size and audit quality. Journal of Accountancy \& Economics, Volume 3, pp. 183199.

Dukic, T. \& Dordevic, M., 2014. Needs and specifics of ensuring effective internal audit. Economics and Organisation, 11(4), pp. 353-356.

Ekanayake, S., 2004. Agency theory, national culture and management control systems. Journal of American Academy of Business, Volume 4, pp. 49-54.

Endaya, K. A. \& Hanefah, M. M., 2013. Internal audit effectiveness: An approach position to develop the theoretical framework. Research Journal of Finance and Accounting, Vol 4. No. 10, pp. 92-102.

Erasmus, L. \& Coetzee, P., 2018. Drivers of stakeholders' view of internal audit effectiveness: Management versus audit committee. Managerial Auditing Journal, Vol. 33 No. 1, pp. 90-114.

Evans, L., 2003. Auditing and audit firms in German before 1931. The Accounting Historians Journal, 30(2), pp. 29-65.

Fama, E. F. \& Jensen, M. C., 1983. Separation of ownership and control. Journal of Law and Economics, Volume 26, pp. 301-325.

Goodwin-Stewart, J. \& Kent, P., 2006. The use of internal audit by Australian companies. Managerial Auditing Journal, 21(1), pp. 81-101.

Gramlin, A. A., Maletta, M. J., Schneider, A. \& Church, B. K., 2004. The role of the internal audit function in corporate governance: A synthesis of the extent of internal audit literature and directions for future research.. Journal of Accounting Literature, Vol 23, pp. 192-244.

Gronewood, U. \& Heerlein, A., 2009. The staff capacity of the internal audit function of German corporations. s.l., American Accounting Association.

Halimah, N. A., Othman, R. \& Kamaruzaman, J., 2009. The effectiveness of internal audit in Malaysian Public Sector.. Journal of Modern Accounting and Auditing, Vol 5 (9), pp. 53-62.

Halimah, N. A., Othman, R. \& Kamaruzaman, J., 2009. The effectiveness of internal ausit in Malaysiaa public sector. Journal od Modern Accounting and Auditing, Vol 5 (9), pp. 53-62.

Holt, T. P. \& DeZoort, T., 2009. The effects of internal audit report disclosure on investors confidence and investment decisions. International Journal of Auditing, 13(1), pp. 61-77.

Hoos, F., Kochetova-Kozloski, N. \& d'Arcy, A. C., 2015. The impotance of the Chief Audit Executive's communication: Experimental evidence on internal audit's judgements in to two masters setting. International Journal of Auditing, Vol. 19 No. 3, pp. 166-181.

Hutchinson, M. \& Zain, M., 2009. Internal audit quality, audit committee independence, growth opportunities and firm performance. Corporate Ownership and Control, 7(2), pp. 50-63.

IIA, 2016. Definition of Internal Auditing. USA: Institute of Internal Auditors.

IIA, 2016. Definition of Internal Auditing. s.1.:Institute of Internal Auditors.

IIA, 2016. The role of audit in public sector governance. Practice guide. Altamonte Springs: The Institute of Internal Auditors.

ILO, 2011. Formulating a national policy on skills development. s.1.:s.n.

Jensen, M. C. \& Meckling, W. H., 1976. Theory of the firm: Managerial behavior,agency cost and ownership structure. Journal of Financial Economics, 3(4), pp. 305-360.

Jiang, L., Andre, P. \& Richard, C., 2014. Determinants of Internal Audit Function Quality: An International study. s.1.:ESSEC Business School.

Kauzya, J. M. \& Balogun, J., 2005. Governance and public administration reforms and innovations in African countries: A focus on achievements, setbacks and future directions. Lagos: Key Press.

Kimotho, N. T., 2014. Factors affecting internal audit independence: A case study of Technical University of 
Mombasa.. Journal of Business \& Management, 6(6).

Krueger, R. A. \& Casey, M. A., 2000. Focus groups: A practical guide for applied research. 4th ed. Thousand Oaks: Sage Publications.

Kurebwa, J., 2015. A Review of Rural Local Government in Zimbabwe from 1980 - 2014. IOSR Journal of Humanities and Social Sciences, Vol 20 Issue. 2, pp. 94-108.

Lenz, R. \& Hahn, U., 2015. A sythesis of empirical internal audit effectiveness literature pointing to new research opportunities. Managerial Auditing Journal, Vol. 30 Issue. 1, pp. 5-33.

Lenz, R. \& Sarens, G., 2012. Reflections on the internal auditing profession: What might have gone wrong?. Managerial Auditing Journal, Vol. 27 No. 6, pp. 532-549.

Limperg institute, 1985. The social responsibility of the auditor. A basic theory on the auditor's function. Amstedam: Limperg Institute.

Lin, S., Pizzin, M., Vargus, M. \& Bardhan, I. R., 2011. The role of internal audit function in the disclosure of material weaknesses. Accounting Review, 86(1), pp. 287-323.

Mebratu, A. A., 2015. Internal audit function and its challenges in public sector governance: Empirical evidence from Amhara National Regional State, Ethiopia. AshEse Journal of Economics, 1(1), pp. 001-012.

Messier, J. \& Schneider, A., 1988. A hierarchical approarch to the external auditor's evaluation of the internal audit function.. Contemporary Accounting Research, 4(2), pp. 337-353.

Mihret, D. G., James, K. \& Mula, J. M., 2010. Antecedents and organisational performance implications of internal audit effectiveness: some propositions and research agenda. Pacific Accounting Review, pp. 224-252.

Mihret, D. G. \& Yismaw, A. w., 2007. Inernal Audit Effectiveness: An Ethiopian public sector case study.. Managerial Auditing Journal, pp. 470-484.

Millichamp, A. \& Taylor, J., 2012. Auditing. 12 ed. Hampshire: Brendon George.

Molina-Azori, J. \& Cameron, R., 2010. The application of mixed methods i organisational research: A literature review. The Electronic Journal of Business Research Methods, 8(2), pp. 95-105.

Neu, D., Everett, J. \& Rahaman, A. S., 2013. Internal auditing and corruption within government: The case of the Canadian spondsorship program. Contemporary Accounting Research, Vol. 30 No. 3, pp. 1223-1250.

Noble, C., 2010. Managing the support stuff identity crisis. Boston: Harvard Business School.

Onumah, J. M. \& Yao Krah, R., 2015. Barriers and catalysts to the effective internal audit in the Ghananian Public Sector. Accounting in Africa, pp. 177-207.

Parker, A. \& Tritter, J., 2006. Focus group method and methodology: current practices and recent debate. International Journal of Research and Method in Education, Volume 29, pp. 23-37.

Pearson, H. \& Sutherland, M., 2017. The complexity of the antecedents influencing accountability in orgaisations. European Business Review, 29(4), pp. 419-439.

Pforsich, H. D., Peterson Kramer, B. K. \& Just, G. R., 2006. Establishing an effective internal audit department. Strategic Finance, Vol. 87 No. 10, pp. 22-29.

Pforsich, H. D., Peterson kremer, B. K. \& Just, G. R., 2008. establishing an internal audit department: A case of Schwan food company. Global Perspectives on Accounting Education, Vol. 5, pp. 1-16.

Pizzini, M., Lin, S., Vargus, M. E. \& Ziegenfuss, D. E., 2012. The impact of internal audit function quality and contribution on audit delays.. Working Paper.

Prawitt, D. F., 2003. Managing the internal audit function. Altamonte Springs, FL: IIA Research Foundation.

Prawitt, D. F., Smith, J. L. \& Wood, D. A., 2009. Internal audit quality and earnings management. The Accounting Review, 84(4), pp. 1255-1280.

Prawitt, D. F., Smith, J. L. \& Wood, D. A., 2009. Internal audit quality and earnings management. The Accounting Review., 84(4), pp. 1255-1280.

Reed, D., 2002. Employing normative stakeholder theory in developing countries a critical theory perspective.. Business and Society, 41(2), pp. 166-207.

Rittenberg, L. \& Anderson, R. J., 2006. A strategic player. Journal of Accounting, Vol. 202 Issue. 1, pp. 51-54.

Roussy, M., 2013. Internal auditor's role: From watchdog to helpers and perfectors of the top manager. Critical perspectives in Accounting, Vol. 24 No. 7-8, pp. 550-571.

Roussy, M. \& Brivot, M., 2016. Internal audit quality: a polysemous notion?. Accounting, Auditing amnd Accountability Journal, Vol. 29 No. 5, pp. 714-738.

Salehi, M., 2011. Audit expectation gap: Concept, nature and trace.. Afracan Journal of Business Management, 5(21), pp. 8376-8392.

Sarens, G. \& Abdolmohammadi, M. J., 2011. Monitoring effects of the internal audit function: Agency theory versus other explanatory variables. International Journal of Auditing, Vol. 15 Issue. 1, pp. 1-20.

Sarens, G. \& De Beelde, I., 2006a. Internal auditors' perceptions about their role and risk management.. Managerial Auditing Journal, Vol 21 (1), pp. 63-80.

Sarens, G. \& De Beelde, I., 2006. Internal auditors' perception about their role in risk management: A comparison bwtween US and Belgian companies.. Managerial Auditing Journal, 21(1), pp. 63-80. 
Sawyer, L. B., 1995. An internal audit philosophy. Internal Auditor, pp. 46-55.

Soh, D. S. B. \& Martinov-Bennie, N., 2011. The internal audit function: Perceptions of internal audit roles, effectiveness anf evaluation. Managerial Auditing Journal, Vol. 26 No. 7, pp. 605-622.

Soh, D. S. \& Martinov-Bennie, N., 2011. The internal audit function: Perceptions of internal audit roles, effectiveness and evaluation.. Managerial Auditing Journal , 26(7), pp. 605-622.

Steinbauer, R., Renn, R. W., Taylor, R. R. \& Njoroge, P. K., 2014. Ethical leadership and followers' moral judgement: The role of followers' perceived accountability and self leadership. Journal of Business Ethics, 120(3), pp. 381-392.

Stewart, J. \& Subramaniam, N., 2010. Internal audit independence and objectivity: Emerging research opportunities. Managerial Auditing Journal, Volume 25, p. 328.

Van Gansberhe, C. N., 2005. Internal Auditing in the public sector: A consultative forum in Nairobi, Kenya, shores up best practices for government audit professionals in developing nations. Internal Auditor, pp. 69-73.

Vinnari, E. \& Skaebaek, P., 2014. The uncertainties of risk management: A field study on risk management internal audit practices in a Finish municipality. Accounting, Auditing and Accountability Journal, Vol. 27 No. 3, pp. 489-726.

Yee, C. S. L., Sujan, A., James, K. \& Leung, J. K. S., 2008. Perceptions of Singaporean internal audit customers regarding the role and effectiveness of internal audit. Asian Journal of Business and Accounting, Vol. 1 No. 2, pp. 147-174.

Zikmund, W. G., 2003. Business research methods. 7th ed. South-Western USA: Thomson.

\section{PROFILES}

\section{First Author - Moses Jachi}

After a distinguished career as an Internal Auditor in the Zimbabwean Local Government sub-sector, which saw him rising to the rank of Chief Audit Executive in two different Local Authorities, Moses Jachi joined the academic carrier at Manicaland State University of Applied Sciences as an Accounting Lecturer. He is a Certified Public Accountant (CPA) and is registered with the Public Accountants and Auditors Board (PAAB) of Zimbabwe as a Public Accountant. He is a $\mathrm{PhD}$ student and his research concentrates on internal audit quality and corporate governance in the public sector. He is currently teaching, researching and/ supervising aspects of Auditing, Financial Reporting and Public Sector Accounting and research at undergraduate level.

\section{Second Author- Lucky Yona}

Lucky Yona is a Professor of Finance and Director of Research and Publication at Eastern and African

Management Institute (ESAMI) in Tanzania He holds a Phd in Finance (Euraka European University), a Doctorate degree in Business Administration (DBA) and MPhil degree from MsM(Netherlands), MBA in Finance (MsM/ESAMI), Bcom (Accounting) degree from University of Dar-es-salaamand B.Th. (Christian Life School of Theology-Georgia, -USA): Lucky is also a Certified Public Accountant (CPA) and a member of Tanzania National Board of Accountants (NBAA). 